\title{
Analysis of Variables of Vessel Calls in a Container Terminal
}

\author{
Keng Bin Loke, Mohamad Rosni Othman, Abdul Hamid Saharuddin, Mohd Naim Fadzil \\ School of Maritime Business and Management, Universiti Malaysia Terengganu, Kuala Terengganu, Malaysia \\ Email: loke.k@umt.edu.my, rosni@umt.edu.my, sdin@umt.edu.my, m.naim@umt.edu.my
}

Received 11 August 2014; revised 12 September 2014; accepted 23 September 2014

Copyright (C) 2014 by authors and Scientific Research Publishing Inc.

This work is licensed under the Creative Commons Attribution International License (CC BY). http://creativecommons.org/licenses/by/4.0/

c) (i) Open Access

\section{Abstract}

The handling efficiency of container terminal may be affected by variables of vessel calls, loading and discharge of container in the terminal. Some of the previous studies indicated that the performance of ship operation would be affected by variables of vessel calls, such as ship size, container loaded and container discharged would affect the handling rate of ship operation, but it didn't clarify on the degree of relationship and lack of variable container shifted/restowed. Therefore, this study would further study on the softcoming, to analyse the relationship between variables of vessel calls with berth turnaround time, that affected the ship operation's performance. Extensive observation and survey activities were conducted at Malaysian's Port and the collected data was based on ship operation delay parameters; like berth turnaround time, total move, total discharge, total load, shift/restow, and length overall of vessels. The initial result showed that total move, total discharge and total load had high correlation with berth turnaround time. The r-value of total move, total discharge and total load are $0.877,0.716$ and 0.804 respectively. Therefore, this study concluded that the berth turnaround time is highly affected by total move, total discharge and total load. Consequently, the research output would be as a decision making tool to port planner.

\section{Keywords}

Berth Turnaround Time, Total Move, Total Discharge, Total Load, Length Overall of Vessel

\section{Introduction}

Various studies on cargo handling are reported in the literature, but studies on the application of variables of container vessel calls are limited. Hence, this study has focused on the linear relationship between berth turnaround times and five independent variables that affect the container handling, to overcome the shortage of the previous studies. The variables are total moved (total containers handled), total discharged (total containers dis- 
charged), total loaded (total containers loaded), total shifted/re-stowed (total containers shifted/re-stowed), and Length Overall of vessels (size of container vessels). Berth turnaround time is used for handling efficiency characterization and the relationships between berth turnaround times and variables of vessel calls in Malaysian major Port are studied. The trend of incremental of vessel size has been driven by the economics of scale. The container vessel capacity is $2500 \mathrm{TEU}$ (Twenty-foot Equivalent Unit) in the year of 1985 and it has increased to 18,000 TEU in the year of 2013. Moreover, the large amount of containers to be loaded and unloaded would promptly increase with the incremental of container vessel's size. Therefore, the size of container vessel and the container operating parameters (total load, total dischage, total move, and total shift/restow) are selected as the factors that affect the berth turnaround time. Robinson [1] indicates that NRT (Net Register Tonnage), total cargo loaded, total cargo unloaded, and total cargo handled have relationship with turnaround time. But, the result didn't given a significant r-value between the dependent and independent variables. The selection of independent variables also further supported by the Malaysian's Port assumed that the five independent variables selected in the study would affect the berth handling performance. Hence, this study move one step further to analyze the degree of relationship between the dependent and independent variables highlighted by Malaysian Port, and another one variable that is not mentioned by Robinson [1], total shift/restow.

Ports as the gateway to a nation, tended to reflect its economy as it grew and developed over the years. There are 13 major ports in Malaysia (Diagram 1). The new ports are established while the old ones will be upgraded. The Malaysian Port sector is now equipped with sufficient infrastructure and equipment to cope with the projected expansion in seaborne trade. Its overall capacities are projected to grow faster. On the whole, Malaysian Ports are already quite specialized and have aligned themselves into the national and regional shipping networks.

\section{Literature Review}

In the nineteenth century, Robinson [1] indicated that the longer the size of vessel the shorter the turnaround time. It overturns the traditional thinking mindset where the longer size of vessel the longer the turnaround time. In order to explore the statistical relationships between turnaround time, ship size and cargo parameters for general cargo ship, a regression analysis has been used to analyze these phenomena at the Port of Hong Kong [1]. Regression analysis was carried out for vessels according to their berthing patterns and size in net registered tonnage (NRT). For each vessel, the turnaround time in hours and minutes is computed from the arrival and departure time and four independent variables are included and they are: NRT, cargo tonnage loaded, cargo tonnage unloaded and total cargo handled. As a result, it shows that the larger general cargo ships the faster the turnaround time compared with smaller ships in port.

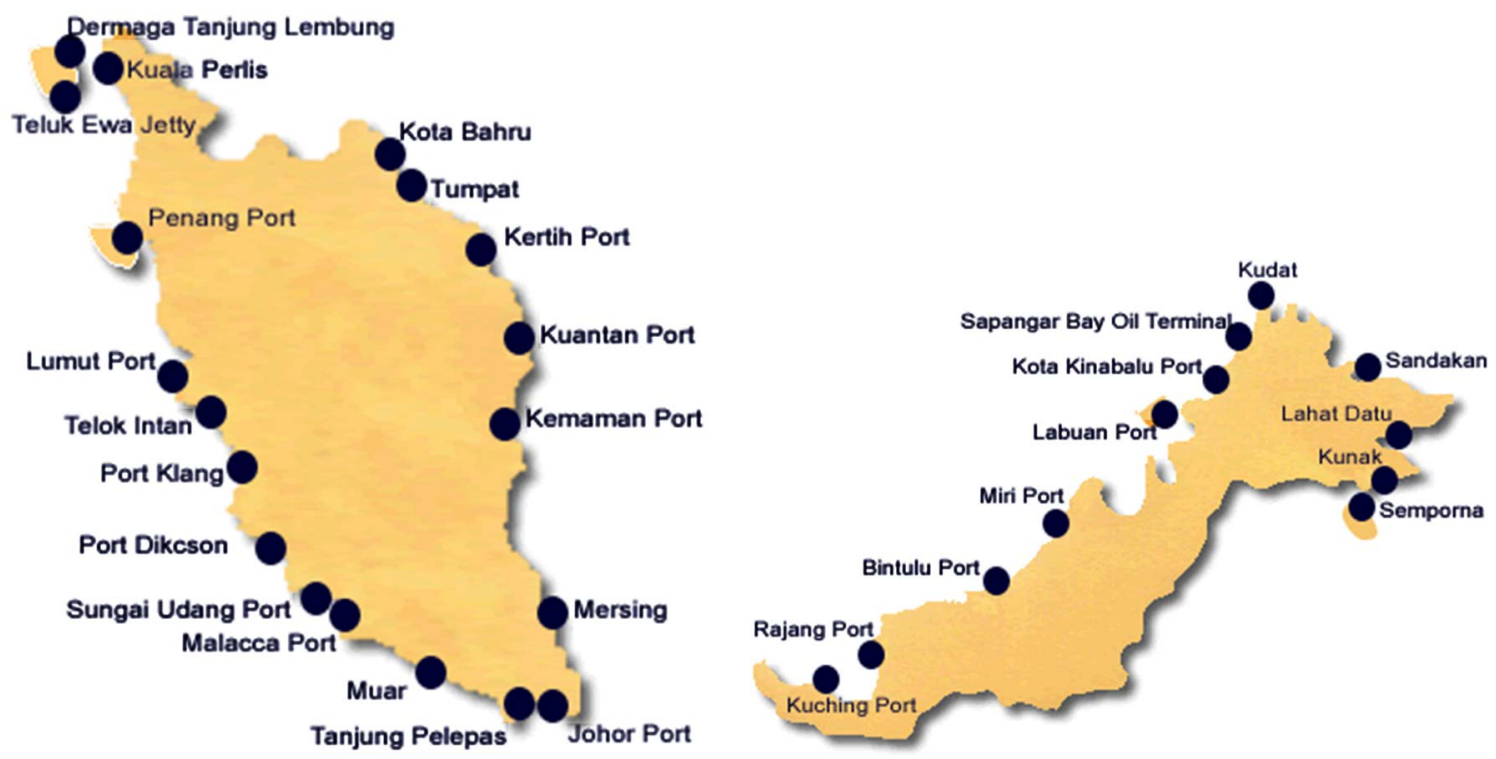

Diagram 1. Distributions of Malaysian Ports. Source: Malaysian Ministry of Transport, 2008. 
Robinson [1] indicated that vessel turnaround time has been defined as the gross time spent by a vessel in a port, and is measured by the total time in hours and minutes in which the ship spent in the port. Akio et al. [2] further described that the turnaround time on a ship included the time for berthing, unloading, loading and departure. The major activities affecting the turnaround time are the unloading and loading processes. Thereafter, Investing in large ship sizes has been the way of increasing the capacity of cargo transportation and raising the profitability of shipping through higher freight income [3]. The trend to increase ship size has been driven by the pursuit of economies of scale. The larger the ship, the lower is the fixed costs per unit of transport cargo [4]. Kevin et al. [5] further described that there is an interdependent relationship between ship size and port design; improvements in cargo handling techniques in ports have created new types of ships and bigger ships are generally more profitable. On the other hand, with increasing ship size it is inevitable that the beginning of the fast turnaround time would increase.

In 1985, only around $10 \%$ of the world container ship capacity was provided by vessels of 2500 TEU or more. In the 1995 this share increased to more than 45 percent of the existing fleet and 60 percent of the tonnage on order. A number of recently delivered vessels already have a capacity of around 6000 TEU [6]. While the company had not officially confirmed it, the latest vessels delivered to Maersk-Sealand for employment in the Europe/Far-East trade route is said to have a capacity of more that 8000 TEU [7]. Over the recent years, ships have strongly increased in size, up to $8000 \mathrm{TEU}$ (twenty feet equivalent unit container). In order to handle large ships efficiently, the turnaround time at the port should be minimal. The large amounts of containers must be loaded and unloaded in a short time span and with a minimum use of expensive equipment [6].

A case study has been done in Kelang Container Terminal (KCT) quay crane allocations, resource allocations and scheduling of the different operations are considered to maximize the performance of the port. Priority assignment based on types of ship and a vessel which carries at least 500 Twenty-Foot Equivalent Units (TEUs) containers was implemented in order to improve the operations within the port. The results showed berth utilization increases when priority is assigned to mainline ships. Results also showed a reduction in the turnaround time for a vessel that has at least 500 TEUs service moves [8].

\section{Methodology}

An extensive secondary data search was collected from the statistics and operation departments of Malaysian Port. There are 1609 ship calls, including mainline and feeder vessels. The data dependent variable is berth turnaround time, and the independent variables are total moves, total discharges, total loads, total shifts and length of overall (LOA). Berth turnaround time for this study is calculated from the time of the first secure until the time of the last tie-up of container vessel that operating at berth. The data is obtained from the port authority that used to calculate the handling rates of the ship operation. Therefore, the collected data is reliable and accurate. Akio et al. [2] proposed that the turnaround time of a vessel is includes the time for berthing, unloading, loading and departure. Robinson [1] stated that the vessel turnaround time has been defined as the gross time spent by a vessel in a port, where the time in hours and minutes that was computed from the arrival and departure time of vessels.

Statistical Package Social Science (SPSS) used for data analysis purpose. The data were checked for normality and reliability test. Normality test is important to determine the applying statistical techniques [9]. The significance level is 0.05 [10]. Reliability test used to check for the accuracy of data collected. Alpha value above or equal to 0.6 can be assumed as good and acceptable [11]. Thereafter, Spearman Correlations were selected to analyze the relationship between dependent and independent variables. If the r-value is equal or above 0.7 , the variables tested is acceptable, and indicated that has a relationship between dependent and independent variable [9].

Based on the dependent and independent variables, some hypotheses are made to test for the relationship among the variables of vessel calls.

Hypotheses:

$\mathrm{H}_{\mathrm{O} 1}$ : There are no significant relationships between berth turnaround times (BTTs) and total moves

$\mathrm{H}_{\mathrm{A} 1}$ : There are significant relationships between BTTs and total moves

$\mathrm{H}_{\mathrm{O} 2}$ : There are no significant relationships between BTTs and total discharges

$\mathrm{H}_{\mathrm{A} 2}$ : There are significant relationships between BTTs and total discharges

$\mathrm{H}_{\mathrm{O} 3}$ : There are no significant relationships between BTTs and total loads

$\mathrm{H}_{\mathrm{A} 3}$ : There are significant relationships between BTTs and total loads 
$\mathrm{H}_{\mathrm{O} 4}$ : There are no significant relationships between BTTs and total shifts/re-stows

$\mathrm{H}_{\mathrm{A} 4}$ : There are significant relationships between BTTs and total shifts/re-stows

$\mathrm{H}_{\mathrm{O} 5}$ : There are no significant relationships between BTTs and LOA

$\mathrm{H}_{\mathrm{A} 5}$ : There are significant relationships between BTTs and LOA

\section{Result and Discussion}

\subsection{Analysis on Normality Test}

Table 1 shows normality test for variables of vessels calls. The Kolmogorov-Smirnov statistic tests the hypothesis that the data are normality distributed. A low significance value $(<0.05)$ indicates that the distribution of the data differ significantly from a normal distribution. Since the significance value for the berth turnaround time, total move, total discharge, shift/restow, and length overall of vessels are 0.000 , it can be assumed as non-normality distribution.

\subsection{Analysis on Reliability Test}

Table 2 shows the reliability test for variables of vessels calls. The table showed that number of cases for this study is 1609 and the variables tested are 6 . The variables tested are berth turnaround time, total move, total discharge, total load, shift/restow, and length overall of vessels. The alpha value for variable of vessels calls is 0.7579. Abu et al. [11] indicated that the alpha value above or equal to 0.6 can be assumed as good and acceptable. Since the result is above 0.6 , therefore the data for variables of vessel calls is acceptable.

\subsection{Correlations Test}

Table 3 showed Spearman correlation analysis for variables of vessel calls. The p-value associated with error acceptable level. If $\mathrm{p}<0.1$, this means that there is more than 0.9 probability ( $90 \%$ chance) that the sample data agree with the hypothesis. Generally p-value accepted at 0.05 or 0.01 in most disciplines. However, $\mathrm{p}<0.1$ is also acceptable, minimum presumption of acceptable level. This study selected $\mathrm{p}<0.1$ as acceptable level for the variables of vessel calls analysis, it desire to get more gentle threshold act as alert signal to port planer. Thus, the port planner would pay attention on it during the working scheduling allocation. The r-values of total moved,

Table 1. Normality test for variables of vessels calls.

\begin{tabular}{cccc}
\hline & \multicolumn{3}{c}{ Kolmogorov-Smirnov $^{\mathbf{a}}$} \\
\hline Berth Turnaround Time & Statistic & df & Sig. \\
Total Move & 0.095 & 1610 & 0.000 \\
Total Discharge & 0.201 & 1610 & 0.000 \\
Total Load & 0.225 & 1610 & 0.000 \\
Shift/Restow & 0.215 & 1610 & 0.000 \\
Length Overall of Vessels (LOA) & 0.386 & 1610 & 0.000 \\
\hline
\end{tabular}

${ }^{\mathrm{a}}$ Lilliefors significance correction.

Table 2. Quay transfer operation reliability analysis.

\begin{tabular}{ccc} 
& Reliability Coefficients & \\
\hline Item & Value \\
\hline No. of Cases & 1609 \\
No. of Items & 6 \\
Alpha & 0.7579 \\
\hline
\end{tabular}


Table 3. Spearman correlations analysis for variables of vessel calls.

\begin{tabular}{cccc}
\hline & & & Berth Turnaround Time \\
\hline Spearman's rho & Berth Turnaround Time & Correlation Coefficient & 1.000 \\
& Sotal Move & Correlation Coefficient & - \\
Total Discharge & Sin. (2-tailed) & $0.877^{*}$ \\
& Correlation Coefficient & 0.000 \\
Total Load & Sin. (2-tailed) & $0.716^{*}$ \\
& Correlation Coefficient & 0.000 \\
Total Shift/Restow & Sin. (2-tailed) & $0.804^{*}$ \\
& Correlation Coefficient & 0.000 \\
Length of Overall of & Sin. (2-tailed) & $0.568^{*}$ \\
Vessels (LOA) & Correlation Coefficient & 0.000 \\
\hline
\end{tabular}

${ }^{*}$ Correlation is significant at the 0.1 level (2-tailed); ${ }^{\mathrm{a}}$ Listwise $\mathrm{N}=1609$.

total discharged and total loaded are $0.877,0.716$ and 0.804 respectively, and this means that these three variables have a strong correlation with berth turnaround times (BTTs). On the other hand, Length Overall of vessels (LOA) and shifted/re-stowed have the r-value of 0.577 and 0.568 respectively, and both of these have a moderate correlation with berth turnaround times. Referring to the interpretation of Connolly and Sluckin, totally moved, total discharged, total loaded, LOA, and shifted/re-stowed have a positive relationship with berth turnaround times. According to McClave, Benson and Sincich (2001), the hypothesis would be accepted if the r-value is equal or above 0.7. The r-value for total moved, total discharged and total loaded are higher that 0.7 . As a result, $\mathrm{H}_{\mathrm{O} 1}, \mathrm{H}_{\mathrm{O} 2}, \mathrm{H}_{\mathrm{O} 3}$ were rejected and $\mathrm{H}_{\mathrm{A} 1}, \mathrm{H}_{\mathrm{A} 2}, \mathrm{H}_{\mathrm{A} 3}$ were accepted. For LOA and shifted/re-stowed cases, both r-values were below 0.7. Therefore, $\mathrm{H}_{\mathrm{O} 4}$ and $\mathrm{H}_{\mathrm{O} 5}$ were accepted and $\mathrm{H}_{\mathrm{A} 4}$ and $\mathrm{H}_{\mathrm{A} 5}$ were rejected.

Initial findings showed that total moves have a strong positive relationship with BTTs; r-value is equal to 0.877. For this reason, the port authority is suggested to pay attention to variable total moves, and to avoid delays caused by container movement. Table 3 showed that total loads affect the BTTs more than total discharges. Therefore, port authority should coordinate the load plan precisely.

\section{Discussion}

The research output shows that total move, total discharge and total load are highly significant influence berth turnaround time in a container terminal. To verify the research output, several similar studies are compared against current study;

I. Kasypi and Muhammad, 2006 [12]

The Kasypi and Muhammad model indicated that berth turnaround time is highly affected by crane allocation and container handle quatity (combined the external and internal factors). The model used linear regression to develop a mathematical matrix that related berth turnaround time with port facility, total load and total discharge.

The current model analysed the variables of vessel calls (focused on external and uncontroable factors) that affected the berth handling performance. This model used correlation to analyse the degree of relationship between dependent variable (berth turnaround time) and independent variables (total container move, total container load, total container discharge, and total container shift/restow). It didn't include the internal and controable factor (crane allocation) and add in additional external and uncontroable factors (total container move and total container shift/restow).

Kasypi and Muhammad model highlighted that crane allocation, total load and total discharge are significant 
related with berth turnaround time. Besides, current model highlighted that total load, total discharge and total move are significant related with berth turnaround time. Both of the research outputs are match, the berth turnaround time is highly related with quantity of container handle (that total load, total discharge and total move).

II. Robinson, 1978 [1]

Robinson model indicated that the larger the general ship the faster the turnaround time. This model didn't analyse the turnaroung time for container vessel. However, the study have determine that the total load, total discharge and total move for both general and container vessel have relationship with turnaround time.

The current model overcomes the softcoming variable proposed by Robinson, which add in size of container vessel and total container shift/restow.

The Robinson model highlighted that total load, total discharge and total move have relationship with turnaround time. The increasing of container handle quantity will increase the turnaround time. The current model highlighted that the total load, total discharge and total move have high relationship with turnaround time. Both of the research outputs are match, the turnaround time is highly related with quantity of container handle (that total load, total discharge and total move).

The research output other than to be used as port authority's operation decision making tool, it also act as policy development guideline for various parties; like government, state holder, industry, and others. The integration between the research output and policy would useful for the establishment of firmness and sustainable policy.

In many industries, the government can influence industry competition through the policies it adopts, and can also effect the position of an industry through regulations, subsidies, or similar means. The availability of local capital in the area and government subsidies are very important to enhance the performance of the port and a culture of trust increases the quality of governance in the port because it lowers transaction costs and enables co-operation Governments have numerous instruments at hand, including investment in infrastructure, the ability to become buyers or suppliers, tax regimes, and various support and subsidies schemes, all of which can mould the competitive environment of the industry.

The following recommendations should help the regulatory bodies and various stakeholders to support the development of container terminals toward sustainable development of the industry:

1. Institutional and legal framework to support the development of this industry and a high degree of centralization of decision making.

2. Initiative to strengthen the communication and interaction among maritime industry players.

3. Develop the maritime network to co-ordinate marketing activities and promote skill development among the maritime communities.

4. Offer attractive financial incentives to industry players through tax exemption on income derived from maritime industry activities, as well as for any person employed by companies involved in the industry.

5. Reduction of the cost of land near maritime infrastructures for companies in the maritime business wanting to set up operations.

6. Close cooperation between maritime agencies (policy maker/regulators) and industry players to ensure that policy and regulations put in place are in keeping with industry dynamics and requirements, and that its growth can be planned thoughtfully and systematically.

7. Attract international players in the field, leading to greater joint ventures and strategic alliances between them and local players. This will enhance efforts to nurture local talent and upgrade the technical skills and capacity of local companies.

8. Investment in new technology to enable the sharing of information between industry players and with the entire supply chain beyond the maritime network.

9. Creating a commercially competitive environment to provide new innovation, value-added products and infrastructure in the sector to encourage business development.

10. Integration between maritime sectors and supply chain.

\section{Conclusions}

Nowadays, new types of ships and bigger ships have been constructed and the size of the vessels increases annually to economics of scale. With the increasing ship size, a ship may carry more containers onboard and the turnaround time may be increased as a result. Therefore, the study has also endeavored into the containers operation on-board (container moves) and the size of vessels. 
A strong correlation relationship between berth turnaround times is shown by total move. The significant r-value of total container handled is 0.877 (Table 3). As a result, the more the containers handled, the more the BTTs are. The total load is the second influencing factor. The significant r-value is 0.804 . Total discharge is the third influencing factor. The significant r-value is 0.716 . Both are strongly correlated with the BTTs.

The fourth influencing factor is the LOA. The significant r-value is 0.577 . The total shift/re-stow, of which

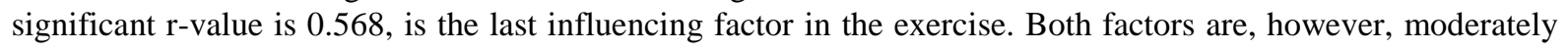
correlated with BTT.

For statistic requirement, r-value is acceptable if it is equal to or above 0.7. As a result, total moves, total loads and total discharges have significant impacts on berth turnaround times. Thus, to reduce the effect of these three variables during the ship operation, the game plan must be organized properly.

\section{Acknowledgements}

We extend our sincere appreciation and indebtedness to the Malaysian Port operation department, statistics department, human resource department, and technical department for the guidance, support and encouragement. We extend our sincere appreciation and indebtedness to UMT and their funder for the guidance, support and encouragement. We would also like to thank the reviewers of this paper for they helpful suggestion.

\section{References}

[1] Robinson, R. (1978) Size of Vessels and Turnround Time. Journal of Transport Economics Policy, 12, 161-178.

[2] Akio, I., Etsuko, N., Stratos, P. and Kazuya, S. (2002) The Containership Loading Problem. International Journal of Maritime Economics, 4, 126-148. http://dx.doi.org/10.1057/palgrave.ijme.9100041

[3] Laine, J.T. and Vepsalainen, A.P.J. (1994) Economics of Speed in Sea Transportation. International Journal of Physical Distribution and Logistics Management, 24, 33-41. http://dx.doi.org/10.1108/09600039410071280

[4] Levander, K. (1993) The Potential for Fast Ship in European Freight Transport. In: Wijnost, N., Peeters, C. and Liebman, P., Eds., European Shortsea Shipping, Proceedings from the First European Research Roundtable Conference on Shortsea Shipping, Lloyds of London Press, London, 22-39.

[5] Kevin, C. and Mahim, K. (2000) Economies of Scale in Large Containerships: Optimal Size and Geographical Implications. Journal of Transport Geography, 8, 181-195. http://dx.doi.org/10.1016/S0966-6923(00)00010-7

[6] Iris, F.A.V. and Rene, D.K. (2002) Transhipment of Containers at a Container Terminal: An Overview. European Journal of Operational Research, 147, 1-16.

[7] Faust, P. (1998) Maritime Transport Market and Policy Developments. The Maritime Institute of Malaysia (MIMA), Malaysia, 45.

[8] Razman, M.T. and Khalid, H. (2000) Simulation and Analysis for the Kelang Container Terminal Operations. Logistics Information Management, 13, 14-20. http://dx.doi.org/10.1108/09576050010306350

[9] McClave, J.T., Benson, P.G. and Sincich, T. (2001) Statistics for Business and Economics. Prentice-Hall, Inc., Upper Saddle River, 1028.

[10] Siegel, S. and John C.N. (1988) Nonparametric Statistics for the Behavioral Sciences. 2nd Edition, McGraw-Hill, New York, 399.

[11] Abu, M.S. and Tasir, Z. (2001) Pengenalan Kepada Analisis Data Berkomputer SPSS 10.0. Venton Publishing, Kuala Lumpur, 299.

[12] Kasypi, M. and Muhammad, Z.S. (2006) A Regression Model for Vessel Turnaround Time. Tokyo Academic, Industry \& Cultural Integration Tour, December. 
Scientific Research Publishing (SCIRP) is one of the largest Open Access journal publishers. It is currently publishing more than 200 open access, online, peer-reviewed journals covering a wide range of academic disciplines. SCIRP serves the worldwide academic communities and contributes to the progress and application of science with its publication.

Other selected journals from SCIRP are listed as below. Submit your manuscript to us via either submit@scirp.org or Online Submission Portal.
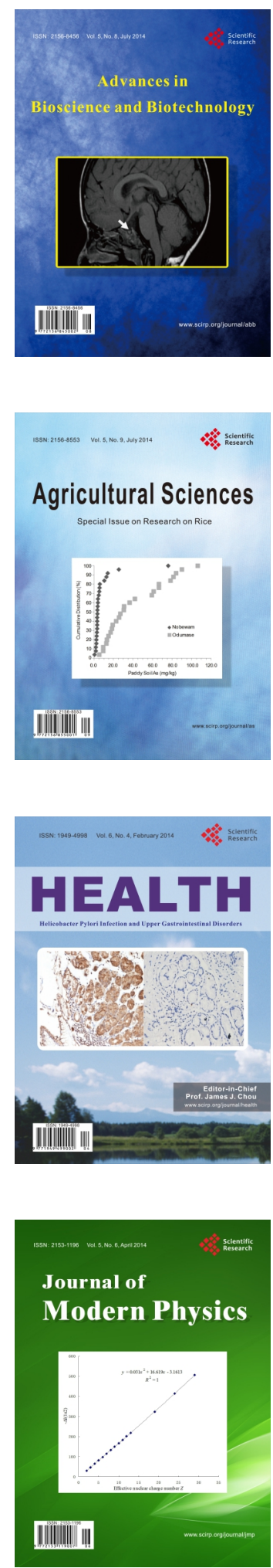
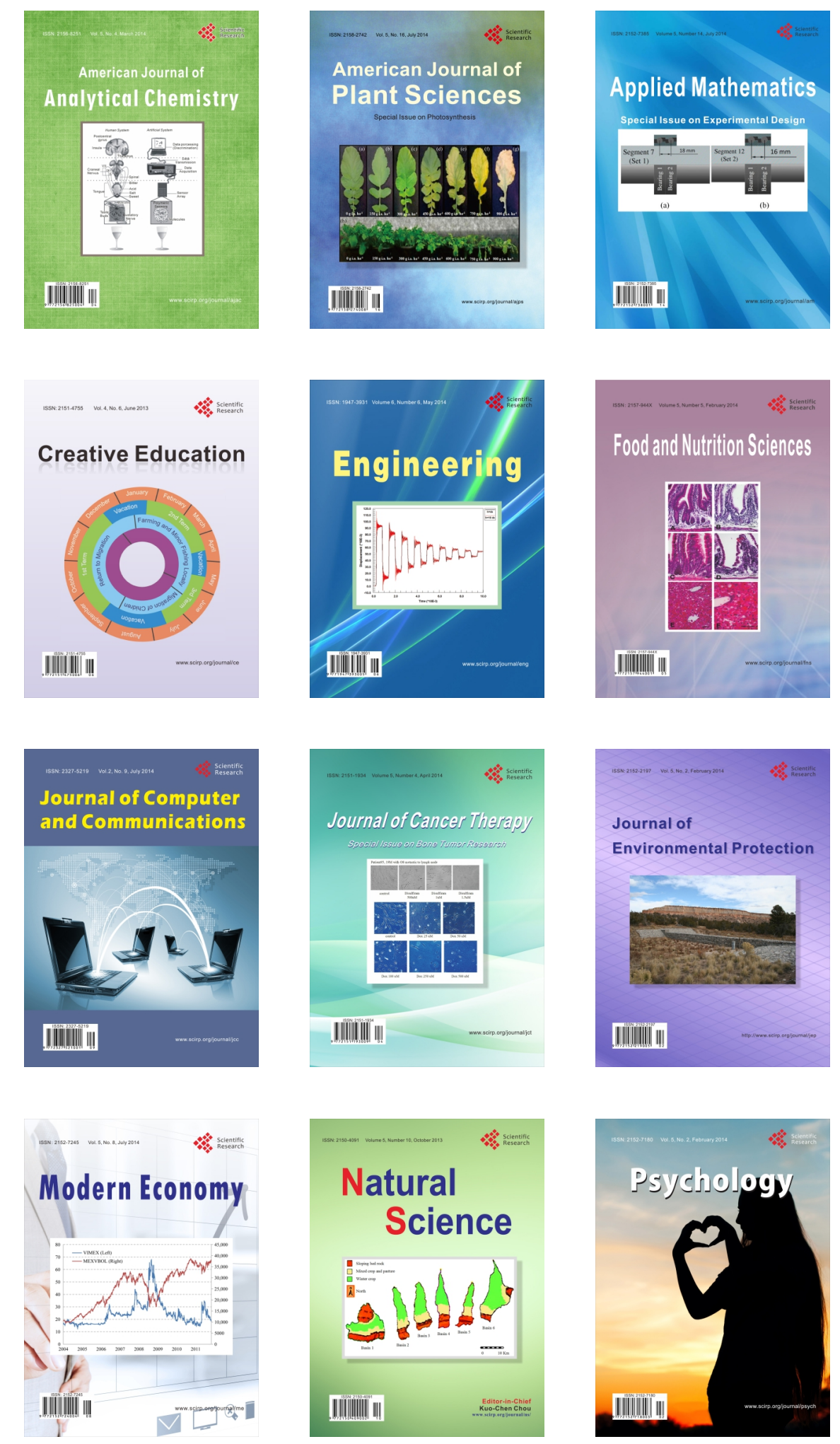